\title{
PEMBINAAN PRESTASI OLAHRAGA SEPAKBOLA DI PUSAT PENDIDIKAN DAN LATIHAN PUTRA BATANG
}

\author{
Wahyu Adhi Nugroho \\ Universitas 17 Agustus 1945 Cirebon \\ email: wahyua2_029@ymail.com
}

\begin{abstract}
Abstrak
Tujuan pembinaan prestasi olahraga sepakbola di Pusdiklat Putra Batang adalah untuk mengembangkan atlet sepakbola secara terencana, berjenjang dan berkelanjutan melalui pembinaan fisik, pembinaan teknik, pembinaan taktik dan pembinaan psikis atau mental. Atlet sepakbola di Pusdiklat Putra Batang berasal dari klub-klub sepakbola lokal dan sekolah sepakbola (SSB) yang berdomisili di Kabupaten Batang dan berhasil lolos seleksi yang dilakukan oleh para pemandu bakat (talents scouting) dan pelatih yang berlisensi. Potensi atlet dan pelatih yang berkualitas yang dimiliki oleh Pusdiklat Putra Batang, dukungan orangtua dan masyarakat seyogyanya dapat meningkatkan prestasi di tingkat regional maupun nasional.. Kekurangan sarana dan prasarana berupa kepemilikan lapangan untuk berlatih, manajemen kepelatihan yang tidak disusun dengan baik, kurangnya perhatian pengurus terhadap keberlangsungan pembinaan serta pembagian tugas yang tidak terstruktur menjadi hambatan dalam berlatih sehingga capaian prestasi Atlet sepakbola di Pusdiklat Putra Batang tidak optimal. Kesimpulan bahwa pembinaan prestasi Sepakbola di Pusdikklat Putra Batang termasuk belum maksimal berdasarkan pada data dan fakta secara nyata di lapangan.
\end{abstract}

Kata Kunci: Model, Pembelajaran, Inkuiri, Konvensional, Self-Esteem

\begin{abstract}
The purpose of coaching soccer sports achievements in Pusdiklat Putra Batang is to develop a planned football athletes, tiered and sustainable through physical training, coaching techniques, coaching tactics and coaching psychic or mental. Football athletes at the Pusdiklat Putra Batang comes from local football clubs and soccer schools ( SSB ) which is domiciled in Batang and successfully passed the selection is done by the scout ( scouting talents) and licensed coaches. Potential athletes and qualified coaches owned by Pusdiklat Putra Batang, parents and community support should be able to improve performance at regional and national level. Shortage of facilities and infrastructure in the form of ownership of the field for practice, management coaching that is not prepared properly, the lack of attention to the sustainability of the development board and the division of tasks be structured so that the performance bottleneck in the practice of football athletes at the Pusdiklat Putra Batang is not optimal. Conclusion that coaching football achievements in Pusdiklat Putra Batang includes enough based on real data and facts on the ground.
\end{abstract}

Keywords: Achievment, Football, Education, Training

(C) 2017 STKIP Muhammadiyah Kuningan 


\section{PENDAHULUAN}

Pembinaan olahraga perlu mempertimbangkan pada karakteristik atlet yang dibina baik secara fisik, teknik taktik, psikologi, sarana dan prasarana, serta kondisi lingkungan pembinaan, dengan tujuan untuk proses pembinaan menuju prestasi yang setinggi-tingginya. Pembinaan merupakan faktor penentu yang sangat penting dalam olahraga, sehingga tujuan prestasi dalam berolahraga dapat tercapai. Munculnya atlet-atlet berbakat tidak lepas dari proses pembinaan yang dilakukan didalam klub olahraga. Klub olahraga merupakan tempat berlangsungnya pembinaan olahraga. Sedangkan prestasi olahraga ditentukan oleh program-program yang disusun oleh pelatih, sarana prasarana yang memadai dana yang menunjang dan partisipasi lingkungan, masyarakat, serta dukungan orang tua yang bersangkutan di klub olahraga tersebut.

Kabupaten Batang yang terdiri dari 16 kecamatan banyak memiliki bibit potensi atlet olahraga khususnya sepakbola. Hal ini terlihat dengan banyak jumlah klub sekolah sepakbola (SSB) yang mencapai jumlah 30 klub dimana rata-rata setiap klub terdiri dari 30 siswa. Sedangkan jumlah pelatih yang telah berlisensi D Pengprov Jawa Tengah sebanyak 26 orang. Salah satu klub sepakbola yang dipersiapkan dan dibina untuk menghadapi event resmi tingkat Provinsi untuk mewakili tingkat Kabupaten adalah klub sepakbola Pusdiklat
Putra Batang. Pemain Pusdiklat Putra Batang ini berasal dari klub-klub lokal dan sekolah sepakbola (SSB) yang berdomisili di Kabupaten Batang dan berhasil lolos seleksi yang dilakukan oleh para pemandu bakat (talents scouting) dan pelatih yang berlisensi. Namun demikian karena masih terbatasnya tenaga kepelatihan dan belum adanya sistem pembinaan prestasi yang sistematis dan berkelanjutan. Hal ini dapat diketahui dari data observasi pada Pusdiklat Putra Batang yang menunjukkan penurunan siswa yang mengikuti latihan dan tenaga kepelatihan yang sering datang terlambat karena para pelatih memiliki profesi lain seperti tenaga pendidik, pegawai kantor dan wirausahawan, hal ini berdampak pada potensi besar dari sumber daya manusia (atlet) belum mampu mencapai prestasi seperti yang diharapkan. Sampai sejauh ini persiapan klub sepakbola Pusdiklat Putra Batang masih belum terlihat baik, hal ini terbukti dengan masih adanya bongkar pasang materi atau komposisi pemain dan program latihan yang belum sistematis, konsisten dan berkelanjutan. Alasan bagi peneliti untuk meneliti pembinaan prestasi olahraga sepakbola di Pusdiklat Putra Batang karena besarnya potensi atlet di wilayah Kota Batang yang terbukti dari 30 klub SSB, namun dari banyaknya klub SSB tersebut belum dapat memberikan prestasi yang diperoleh secara berkesinambungan dan mengelami peningkatan dari tahun ke tahun. 
Pembinaan prestasi di Pusdiklat

Putra Batang berdasarkan hasil observasi di lapangan dalam waktu terakhir mengalami penurunan peserta, pemindahan lokasi latihan dari Stadion Muhammad Sarengat ke lapangan Kampus Dracik Batang, secara tidak langsung menyebabkan minat berlatih para siswa Pusdiklat Putra Batang mengalami penurunan, perbedaan kualitas lapangan dan letak lapangan kampus Dracik yang kurang strategis menyebabkan siswa malas untuk datang mengikuti latihan. Lapangan kampus Dracik adalah sarana prasarana bagi masyarakat dan sekolah yang ada disekitar untuk bermain dan digunakan praktik olahraga, hal ini jelas berpengaruh pada tingkat optimalisasi dan penyampaian materi latihan di Pusdiklat Putra Batang. Para siswa menjadi kurang fokus dan konsentrasinya terganggu oleh kegiatan olahraga maupun aktifitas masyarakat sekitar lapangan. Pusdiklat Putra Batang memiliki sembilan tenaga pelatih namun hanya beberapa yang masih aktif, hal ini disebabkan karena adanya manjemen kepelatihan yang tidak disusun dengan baik, serta pembagian tugas yang tidak terstruktur.

Menurut Alisjahbana (2008), dalam membangun sistem pembinaan olahraga, ada beberapa komponen utama yang perlu diperhatikan. Komponen-komponen utama tersebut terdiri dari:1) Fungsi, yang mengarahkan dan menjadi penarik, 2) Manajemen, untuk merencanakan, mengendalikan, menggerakkan, dan mengkoordinasikan seluruh kegiatan sehingga tertuju pada tujuan, guna meningkatkan efisiensi teknis dan ekonomis, 3) Ketenagaan, di mana saat ini isu nasional dalam pembinaan olahraga masih berpusat pada kelangkaan tenagatenaga profesional yang dipersiapkan secara khusus untuk membina olahraga melalui program pendidikan atau pelatihan, 4) Tenaga Pembina, beberapa permasalahan utama yang terkait dengan komponen ini berhubungan dengan belum adanya standar persyaratan tenaga profesional pembina olahraga yang dibangun secara sistemik. Pengakuan formal dari pemerintah terhadap jabatan ini masih minim, termasuk di dalamnya pengakuan terhadap status dan kompetensi mereka yang berimplikasi pada sistem penghargaan dan jaminan sosial yang mereka terima, 5) Atlet atau Olahragawan, tak jauh berbeda dengan komponen tenaga pembina, faktor-faktor klasik seperti penghargaan serta jaminan sosial yang mereka terima menjadi permasalahan serius yang ikut menentukan kegairahan pencapaian prestasi yang secara keseluruhan ikut menentukan upaya membangun profesionalisme olahraga nasional, 6) Struktur Program dan Isi, yang berkenaan dengan program-program umum serta kegiatan keolahragan yang dirumuskan dalam kalender olahraga nasional yang dapat meningkatkan mutu pembinaan. Sumber-sumber belajar, seperti 
buku petunjuk, buku ajar, rekaman film, dan lain-lain, termasuk di dalamnya informasi secara meluas tentang pronsip pembinaan yang disajikan secara praktis, 7) Metodologi dan Prosedur Kerja, yang mencakup pengembangan dan penerapan teknik serta metode pembinaan dan pemanfaatan temuan-temuan baru guna memaksimumkan efisiensi dan efektivitas pembinaan, 8) Evaluasi, untuk mendukung pengendalian program agar mencapai tujuan yang diharapkan, termasuk di dalamnya adalah pengendalian mutu, peningkatan efisiensi dan efektivitas pembinaan, 9) Dana, problem utama yang membelit komponen ini berkisar pada sumber pendanaan yang masih minim serta alokasi dan pemanfaatannya secara tepat dan opklubal.

\section{Undang-Undang Nomor 3 Tahun} 2005 Pasal 1, ayat (3) menyatakan bahwa sistem keolahragaan nasional adalah keseluruhan aspek keolahragaan yang saling terkait secara terencana, sistematis, terpadu, dan berkelanjutan sebagai satu kesatuan yang meliputi pengaturan, pendidikan, pelatihan, pengelolaan, pembinaan, pengembangan, dan pengawasan untuk mencapai tujuan tujuan keolahragaan nasional. Dalam penjelasan Undang-Undang Nomor 3 Tahun 2005 tentang Sistem Keolahragaan Nasional mengatakan sistem pengelolaan, pembinaan, dan pengembangan keolahragaan nasional diatur dengan semangat kebijakan otonomi daerah guna mewujudkan kemampuan daerah dan masyarakat yang mampu secara mandiri mengembangkan kegiatan keolahragaan. Penanganan keolahragaan tidak dapat lagi ditangani secara sekadarnya tetapi harus ditangani secara professional. Sistem pembinaan dimulai dari institusi yang terkecil, yaitu keluarga, baru kemudian bergerak kearah lingkungan yang lebih besar seperti masyarakat, sekolah, dan klub. Pembinaan olahraga dilakukan melalui tiga domain, yakni olahraga pendidikan, olahraga rekreasi, dan olahraga prestasi. Berdasarkan kerangka pemikiran tersebut, dikenal tiga pilar bangunan olahraga yaitu pendidikan jasmani/olahraga pendidikan, olahraga rekreasi, dan olahraga prestasi.

Atlet berbakat tidak dapat dengan sendirinya akan mencapai prestasi tertinggi apabila tidak didukung dengan pembinaan yang baik. Secara garis besar ada beberapa faktor yang mempengaruhi dalam peningkatan prestasi maksimal secara efektif (KONI, 1997:15). Adapun faktorfaktor tersebut antara lain: 1). faktor internal pemain, meliputi bakat, minat, dan lain-lain, 2) manajemen organisasi yang baik, 3) program pembinaan, 4) pemanfaatan sarana dan prasarana pendukung. Para ahli olahraga seluruh dunia sependapat perlunya tahap-tahap pembinaan untuk menghasilkan prestasi olahraga yang tinggi, yaitu melalui tahap pemasalan, pembibitan, dan pencapaian 
prestasi, sehingga lahirlah teori piramida dalam pembinaan olahraga.

$$
\text { Rusli Lutan (1992:30-32), }
$$

berpendapat bahwa prestasi terbaik hanya akan dapat dicapai bila pembinaan dapat dilaksanakan dan tertuju pada aspek-aspek pelatihan seutuhnya yang mencakup: 1) kepribadian atlet untuk dapat beradaptasi dalam olahraga, dibutuhkan sifat-sifat tertentu yang sesuai dengan tuntutan cabangnya yaitu sikap positif, loyal terhadap kepemimpinan, rendah hati, dan semangat bersaing dan berprestasi, 2) kondisi fisik pembinaan kondisi fisik tertuju pada komponen kemampuan fisik yang dominan untuk mencapai prestasi .Di samping terdapat kebutuhan yang bersifat umum, setiap cabang olahraga juga memerlukan pembinaan komponen kondisi fisik yang spesifik, 3) keterampilan teknik tertuju pada penguasaan keterampilan teknik yang rasional dan ekonomis dalam suatu cabang olahraga, bila kekuatan, stamina, dan kecepatan sudah berkembang, maka atlet dapat mengalami peningkatan dalam penguasaan keterampilan teknik, 4) Keterampilan taktis, atlet harus dapat memanfaatkan kondisi fisik, keterampilan dan kondisi psikologis guna merespon kekuatan atau kelemahan lawannya secara efektif, 5) Kemampuan mental karena ditaksir sekitar 90-95 \% variasi prestasi sebagai pengaruh kemampuan mental. Pembinaan mental dimaksudkan antara lain agar atlet mampu menanggulangi stress dari beban latihan yang berat, dan atlet memiliki stabilitas emosi yang tangguh.

Pembinaan olahraga sejak usia muda merupakan hal yang sangat penting sekali dalam menciptakan atlet yang berhasil. Karena dengan diberikannya pembinaan sejak masih usia muda maka akan menghasilkan kualitas atlet yang baik, walaupun ini bukan hal mutlak, tapi setidaknya dengan pengenalan yang baik itu, teknik, fisik, dan mental pengenalan materi olahraga bagi usia muda akan terbentuk. Bompa (1994) membagi tahapan usia dalam pencapaina prestasi olahraga dalam 3 kategori, yaitu : 1) tahapan permulaan (persiapan) yaitu usia 10-12 tahun, 2) tahapan spesialisasi, antara usia 11-13 tahun, 3) tahapan prestasi puncak, antara usia 18-24 tahun.

\section{METODE}

Penelitian ini menggunakan metode kualitatif dengan alasan penelitian kualitatif mampu memberikan gambaran secara lengkap dan mendalam tentang pembinaan prestasi olahraga sepakbola di Pusdiklat Putra Batang. Peneliti berusaha mengungkapkan makna tentang "pembinaan prestasi olahraga sepakbola di Pusdiklat Putra Batang". Data yang terkumpul terbentuk kata-kata tulisan yang meliputi catatan laporan dan foto-foto (dokumentasi). Lokasi penelitian adalah di Pusat Pendidikan dan Latihan (Pusdiklat) Putra Batang. Adapun alasan dipilihnya tempat atau lokasi tersebut sebagai obyek 
penelitian yaitu: 1) penelitian tentang pembinaan prestasi olahraga sepakbola di Pusdiklat Putra Batang belum pernah ada, 2) keterbatasan tenaga kepelatihan dan dan sistem pembinaan yang baik belum dapat mengolah bibit potensi atlet dengan terarah untuk tujuan prestasi, 3) belum adanya pembinaan olahraga yang terprogram secara sistematis dan berkelanjutan bagi atlet atau calon atlet, 4) ketersediaan sarana dan prasarana berlatih sepakbola yang belum memadai, 5) belum adanya program latihan sepakbola yang sistematis dan berkelanjutan. Subjek dalam penelitian ini yaitu: atlet 3 orang, pelatih 3 orang, orangtua atlet 3 orang dan masyarakat sekitar yang diwakili oleh 3 orang responden. Pusdiklat Putra Batang. Teknik pengumpulan data menggunakan observasi, wawancara dan dokumentasi. Analisis data menurut Bogdan, dalam Sugiyono (2009:334) adalah proses mencari dan menyusun secara sistematis data yang didapat/diperoleh dari hasil interview, observasi, catatan lapangan, dan bahanbahan lain, sehingga dapat dipahami, dan temuannya dapat diinformasikan kepada orang lain. Pendekatan yang digunakan dalam analisis data ini adalah pendekatan analisis kualitatif. Menurut Sugiyono (2009 : 338) terdiri dari tiga alur (pokok) yang saling berhubungan, bersamaan adalah (1) reduksi data (2) penyajian data, (3) penarikan kesimpulan (verifikasi).

\section{HASIL PENELITIAN}

Berdasarkan penelitian yang telah dilakukan pada Pusdiklat Putra Batang diperoleh hasil penelitian sebagai berikut:

\section{1) Tujuan Pembinaan Prestasi Sepakbola di Pusdiklat Putra Batang}

Berdasarkan hasil obervasi dan wawancara dengan informan penelitian diperoleh informasi bahwa tujuan pembinaan prestasi di Pusdiklat Putra Batang ini pada intinya adalah mencetak kader-kader pemain sepakbola yang handal dan berprestasi yang program latihannya sudah disesuaikan dengan kurikulum FIFA dan PSSI untuk masyarakat di Kabupaten Batang khususnya dan Indonesia pada umumnya.

\section{2) Peranan Atlet dan Pelatih dalam Pembinaan Prestasi Sepakbola di Pusdiklat Putra Batang .}

Berdasarkan hasil obervasi dan wawancara dengan informan penelitian diperoleh informasi bahwa

(a) Peran atlet berpengaruh karena atlet merupakan sasaran dari proses pembinaan sehingga prestasi klub sepakbola juga akan dipengaruhi oleh para atletnya. Peranan atau partisipasi atlet Pusdiklat Putra Batang sangat aktif. Subjek penelitian menyadari peran dan konsekwensinya sebagai atlet sepak bola. Dinyatakan bahwa kualitas atlet Pusdiklat Putra Batang memang sudah terkenal di masyarakat 
sekitar Batang. Informan juga sudah memberikan apresiasi yang positif terhadap teknik individu permainan anak-anak Pusdiklat Batang termasuk kriteria bagus.

(b) Pelatih mempunyai peranan yang sangat penting dalam pencapaian prestasi di Pusdiklat Putra Batang. Peran pelatih tercermin dalam pendapat dan tingkah lakunya dalam melaksanakan tugasnya sebagai coach dalam membina atletnya untuk mengembangkan secara optimal kesehatan, fisik, mental, dan sosial. Cerminan tersebut nampak dalam tugasnya untuk mengembangkan keterampilan motorik, prestasi, perilaku etis, moral yg baik, berkepribadian yang baik, dan respek terhadap orang lain. Pelatih di Pusdiklat Putra Batang tersebut mempunyai gaya tipe kepimpinan yang demokratis karena dapat bersikap akrab dengan atlet, mau mendengar pendapat atlet, tidak banyak memberikan instruksi atau perintah. Hal tersebut menjadikan atlet di Pusdiklat Putra Batang merasa diakui, dihargai, merasa puas dan memiliki hubungan erat dengan anggota sesama team. Pelatih juga menerapakan kedisiplinan dalam berlatih dengan tujuan fokus terhadap latihan dan memiliki motivasi kuat untuk menang dalam pertandingan. Sehingga atlet lebih menekankan pada tugas (task oriented), lebih efisien segala usaha ditujukan pada tugas yang harus diselesaikan, tidak banyak membuang waktu untuk komunikasi pribadi dengan atlet dan antara atlet.

\section{3) Sarana Prasarana dan Pendanaan Sepakbola yang Dimiliki oleh Pusdiklat Putra Batang.}

Berdasarkan hasil obervasi dan wawancara dengan informan penelitian diperoleh informasi

\section{(a) Sarana dan Prasarana}

Berdasarkan hasil observasi dan wawancara dari subjek dan informan penelitian dapat ditarik pengertian bahwa faktor utama sarana dan prasarana yang kurang mendukung pembinaan prestasi di Pusdiklat Putra Batang adalah lapangan. Lapangan merupakan hal yang paling pokok dalam permainan sepak bola. Semakin mendukung prasarana-sarana semakin bagus capaian prestasi olahraga Berikut ini disajikan tabel peralatan yang dimiliki oleh.

Tabel 1

Peralatan yang Dimiliki Pusdiklat Putra Batang

\begin{tabular}{|l|c|c|c|c|c|c|}
\hline \multirow{2}{*}{ No } & \multirow{2}{*}{ Sarana } & \multicolumn{4}{|c|}{ Jumlah } & \multirow{2}{*}{ Ket } \\
\cline { 3 - 5 } & $\begin{array}{c}\text { Baik } \\
\text { Sekali }\end{array}$ & Baik & Sedang & Rusak & \multirow{2}{*}{} \\
\hline
\end{tabular}




\begin{tabular}{|l|l|c|c|c|c|l|}
\hline 1 & Bola sepak & & 10 & 5 & 15 & $\begin{array}{l}\text { Standar } \\
\text { nasional }\end{array}$ \\
\hline 2 & Cone & - & 50 & - & - & $\begin{array}{l}\text { Standar } \\
\text { Internasional }\end{array}$ \\
\hline 3 & Rompi Latihan & 22 & 22 & 22 & - & $\begin{array}{l}\text { Standar } \\
\text { nasional }\end{array}$ \\
\hline 4 & Pompa bola & - & 1 & - & - & $\begin{array}{l}\text { Standar } \\
\text { nasional }\end{array}$ \\
\hline 5 & Gawang portabel & & 1 set & - & - & $\begin{array}{l}\text { Standar } \\
\text { nasional }\end{array}$ \\
\hline 6 & Gawang kecil & - & 1 set & - & 1 & $\begin{array}{l}\text { Standar } \\
\text { nasional }\end{array}$ \\
\hline 7 & Stop watch & 1 & - & - & - & $\begin{array}{l}\text { Standar } \\
\text { Internasional }\end{array}$ \\
\hline 8 & peluit & 1 & - & - & - & $\begin{array}{l}\text { Standar } \\
\text { nasional }\end{array}$ \\
\hline
\end{tabular}

Berdasarkan tabel 1 dapat diketahui bahwa Pusdiklat Putra Batang memiliki sarana bola sepak dengan kondisi baik 10 buah, sedang 5 buah dan rusak 15 buah. Bola yang dimiliki Pusdiklat Putra Batang memiliki 3 ukuran, yaitu 3, 4, dan 5. Besar kecilnya bola disesuaikan dengan usia pemain. Bola ini dibuat dari pola-pola segi lima berwarna putih dan hitam yang dijahit menjadi satu. Semua bola yang dimiliki sudah sesuai dengan standar nasional. Sarana dan prasarana lain yang dimiliki Pusdiklat Putrta Batang antara lain; Cone sebanyak 50 buah dalam kondisi baik, rompi latihan 22 potong dalam kondisi baik seklali, 22 potong dalam kondisi baik dan 22 potong dalam kondisi sedang, pompa bola 1 unit dengan kondisi baik, gawang portable 1 set dalam kondisi baik, gawang kecil 1 set dalam kondisi baik, stop watch 1 unit dalam kondisi sangat baik, peluit 1 unit dalam kondisi baik. (b) Pendanaan

Pendanaan merupakan masalah utama yang menghambat pembinaan prestasi di Pusdiklat Putra Batang. Sumber pendanaan yang masih minim serta alokasi dan pemanfaatannya yang masih belum tepat. Dengan kata lain, Pusdiklat Putra Batang masih membutuhkan dana yang besar guna menunjang tercapainya prestasi yang bagus.

\section{4) Dukungan Pengurus terhadap Pembinaan Prestasi Sepakbola di Pusdiklat Putra Batang}

Berdasarkan hasil obervasi dan wawancara dengan informan penelitian diperoleh informasi bahwa pelatih di Pusdiklat Putra Batang juga merangkap sebagai pengurus. Pengurus mendukung sepenuhnya semua kegiatan pembinaan atlet guna tercapainya prestasi yang baik. pengurus Pusdiklat Putra Batang memberikan dukungan terhadap pembinaan 
atlet berprestasi yang ditunjukkan dengan pemberian hadiah financial, pemberian fasilitas akomodasi ketika team melakukan pertandingan dan meraih kemenangan.

\section{5) Dukungan Orangtua terhadap}

Pembinaan Sepakbola di Pusdiklat Putra Batang

Berdasarkan hasil obervasi dan wawancara dengan informan penelitian diperoleh informasi bahwa dukungan orang tua sangat bagus dengan adanya pembinaan sepak bola seperti ini. Dibuktikan banyak orang tua yang menyekolahkan anaknya di Pusdiklat Putra Batang ini. Dukungan positif dari para orang tua ini dapat dilihat dari antusiasme orangtua dalam memberi semangat dan menjembatani anak-anak mereka untuk berlatih di Pusdiklat Putra Batang. Dukungan moral dan financial dari orangtua diberikan pada atlet. Orangtua merasa sangat senang anak memiliki kegiatan yang positif, menambah kualitas hidup sehat dan berprestasi. Hal itu membuktikan bahwa keberadaan Pusdiklat Putra Batang menjadi tempat kebanggaan bagi para orang tua yang anaknya bercitacita menjadi pemain bola.

\section{6) Dukungan Masyarakat Sekitar Pusdiklat terhadap Pembinaan Prestasi Sepakbola di Pusdiklat Putra Batang}

Berdasarkan hasil obervasi dan wawancara dengan informan penelitian diperoleh informasi bahwa masyarakat merasa senang, bangga dan terhibur dengan adanya pembinaan pembinaan sepak bola di Pusdiklat Putra Batang. Hal yang perlu diperhatikan dan penting bagi masyarakat adalah keamanan dan ketertiban berkaitan dengan keberadaan pembinaan prestasi sepakbola di Pusdiklat Putra Batang. Masyarakat mendukung keberadaan pembinaan prestasi sepakbola di Pusdiklat Putra Batang. Masyarakat mau datang dan melihat atlet berlatih dan bertanding di lapangan. Hal tersebut menunjukkan masyarakat mengapresiasi kegiatan berlatih dan bertanding atlet Pusdiklat Putra Batang. Dukungan masyarakat itu berpengaruh terhadap pembinaan prestasi atlet karena atlet menjadi termotivasi untuk memberikan tampilan permainan yang baik, bersemangat dalam berlatih.

\section{7) Program Latihan Sepakbola yang} telah dilaksanakan di Pusdiklat Putra Batang

Berdasarkan hasil obervasi dan wawancara dengan informan penelitian diperoleh informasi bahwa program latihan sepakbola yang telah dilaksanakan di Pusdiklat Putra Batang adalah sesuai dengan kurikulum standar FIFA maupun PSSI sesuai tingkatan usia. Berdasarkan hasil wawancara dengan subjek dan informan penelitian diperoleh informasi bahwa jadwal latihan sepakbola dilaksanakan 3 kali dalam sau minggu yaitu pada hari Selasa jam 14.00-16.30 wib, hari Kamis jam 14.00- 16.30 wib dan hari Minggu jam 07.00- 09.30 wib. Pola 
pembinaan pemain sepakbola Pusdiklat putra Batang diarahkan dari Pemerintah Daerah. Pengurus Pusdiklat Putra Batang mencari atlet sepakbola dari klub-klub sepakbola yang ada di wilayah kabupaten Batang terutama jika menghadapi turnamen atau kejuaraan sepakbola. Pemain yang memiliki kualitas baik dicari dan diambil dari klub-klub sepakbola yang ada di Kabupaten Batang kemudian dilatih di Pudiklat Putra Batang.

Pola pembinaan pemain sepakbola Pusdiklat putra Batang diarahkan dari Pemerintah Daerah. Pengurus Pusdiklat Putra Batang mencari atlet sepakbola dari klub-klub sepakbola yang ada di wilayah kabupaten Batang terutama jika menghadapi turnamen atau kejuaraan sepakbola. Pemain yang memiliki kualitas baik dicari dan diambil dari klub-klub sepakbola yang ada di Kabupaten Batang kemudian dilatih di Pudiklat Putra Batang.

Program-program yang disusun telah dilaksanakan dengan baik mencakupi halhal berikut ini:

1) Penyusunan program latihan disusun dan disesuaikan dengan kurikulum standar FIFA maupun PSSI sesuai tingkatan usia.

2) Program latihan perencanaan jangka menengah juga disusun berdasar kurikulum yang mengacu pada standar FIFA

3) Perencanaan jangka menengah disusun berdasarkan perencanaan program pelatihan perencanaan jangka panjang sesuai dengan kurikulum FIFA dalam bentuk buku pedoman sesuai dengan rentang umur dari tingkatan yang berbeda dan program latihannya menyesuaikan dengan usia atlet

4) Program pelatihan mengacu pada sasaran/target yang dicapai Pusdiklat dalam waktu satu tahun (periode).

5) Kemampuan pelatih dalam mengorganisir kegiatan Pusdiklat (organizing) adalah denganmengajak semua komponen untuk rapat. Jadi setiap ada kegiatan ataupun even pengurus melakukan rapat untuk membahas masalah dan mencari solusinya bersama.

6) Program pelatihan dinilai secara periodik. Program latihan ini dimulai dari tingkatan dasar seperti passing, dan pada periode berikutnya menuju teknik yang lebih memacu pada skill, dan menyesuaikan pada kurikulum.

7) Program pelatihan diperbaiki dan disempurnakan pada setiap akhir tahun. Dalam setiap akhir periode pelaith selalu melakukan evaluasi baik dari program latihan dan pelaksanaan kegiatan dalam even resmi, namun bentuknya dalam sebuah rapat antara pengurus dan komite.

Disajikan juga program-program terencana yang ada, hanya saja pelaksanaannya belum maksimal karena berbagai faktor. 
1) Perencanaan jangka menengah yang didasarkan pada kondisi Pusdiklat (kelemahan, keunggulan peluang, dan tantangan) belum berjalan dengan baik karena pedoman perencanaan terkadang tidak berjalan dengan yang diinginkan. Salah satu fatornya adalah keterbatasan pelatih sarana prasarananya dan kondisi atlet.

2) Perencanaan program pelatihan jangka menengah penjabarannya belum tersusun secara tertulis. Kegiatan penyusunan terbatas pada anggaran dan hanya pada saat waktu pelaksanaan saja.

3) Penyusunan program pelatihan tahunan secara tertulis hanya pada buku acuan kurikulum, untuk program latihan sudah dibuat tapi tidak secara rutin,

4) Program pelatihan tahunan yang disusun berdasarkan perencanaan jangka menengahbelum baik terkadang tidak sesuai dengan program, materinya menyesuaikan dengan kondisi dan mengalir begitu saja.

5) Program Pusdiklat dijabarkan secara jelas namun dalam pelaksanaannya memang tidak semua terencana dan berjalan karena keterbatasan tenaga dan Sumber daya manusianya.

6) Dalam mengkoordinasi pelaksanaan program pelatihan sebetulnya sudah ada pembagian tugas pelatih yang mana meliputi aspek fisik teknik, dan skill, tapi dalam pelaksanaannya karena memilki tenaga kepelatihan yang terbatas kegiatan tersebut dirangkap oleh satu orang.

7) Program pelatihan yang dilaksanakan kadang tidak sesuai rencana karena fakta dilapangan mengalami beberapa kendala, faktor anak yang sering tidak berangkat kemudian kesibukan para pelatih yang mempunyai beberapa profesi lainterkadang membuat latihan kurang intensif.

8) Kemampuan pelatih dalam mengimplementasikan program pelatihan dengan menggerakkan staf, asisten, dan sumber daya Pusdiklat lainnya (actuating)belum berjalan karena dalam kurun waktu beberapa tahun ini banyak tenaga pelatih yang sudah tidak melatih lagi.

9) Pelaksanaan program pelatihan belum dipantau secara terencana di Pusdiklat ini mengalami krisis tenaga, baik pelatih maupun pengurus, jadi pemantauan belum dijalankan secara baik.

Rencana yang disusun baik memang berdampak pada hasil program latihan, tapi ada beberapa faktor pendukung misalnya kemampuan pelatih, kemudian kondisi lingkungan, atlet dan sebagainya, dimana semua komponen ini harus bersinergi satu sama lain. Simpulan data pembinaan prestasi atlet sepak bola di Pusdiklat Putra 
Batang ditampilkan dalam matrik berikut

ini:

Tabel 2

Matrik Hasil Pengumpulan Data Pembinaan Prestasi

Di Pusdiklat Putra Batang

\begin{tabular}{|c|c|c|c|c|c|}
\hline \multirow{2}{*}{ No } & \multirow{2}{*}{ Variabel/Aspek yang dinilai } & \multicolumn{3}{|c|}{ Hasil } & \multirow{2}{*}{ Sumber data } \\
\hline & & B & $\mathrm{C}$ & & \\
\hline 1 & $\begin{array}{l}\text { Tujuan pembinaan di pusdiklat putra } \\
\text { Batang }\end{array}$ & $\sqrt{ }$ & - & 1 & $\begin{array}{l}\text { Tujuan pembinaan di } \\
\text { pusdiklat putra } \\
\text { Batang }\end{array}$ \\
\hline 2 & $\begin{array}{l}\text { Peranan atlet dan pelatih dalam } \\
\text { pembinaan prestasi sepakbola di } \\
\text { Pusdiklat Putra Batang }\end{array}$ & $\sqrt{ }$ & - & 2 & $\begin{array}{l}\text { Peranan atlet dan } \\
\text { pelatih dalam } \\
\text { pembinaan prestasi } \\
\text { sepakbola di } \\
\text { Pusdiklat Putra } \\
\text { Batang }\end{array}$ \\
\hline 3 & $\begin{array}{l}\text { Sarana prasarana olahraga dan } \\
\text { Pendanaan sepakbola di Pusdiklat } \\
\text { Putra Batang }\end{array}$ & - & $\sqrt{ }$ & 3 & $\begin{array}{l}\text { Sarana prasarana } \\
\text { olahraga dan } \\
\text { Pendanaan } \\
\text { sepakbola di } \\
\text { Pusdiklat Putra } \\
\text { Batang }\end{array}$ \\
\hline 4 & $\begin{array}{l}\text { Dukungan pengurus terhadap } \\
\text { pembinaan prestasi sepakbola di } \\
\text { Pusdiklat Putra Batang }\end{array}$ & - & $\sqrt{ }$ & 4 & $\begin{array}{l}\text { Dukungan pengurus } \\
\text { terhadap pembinaan } \\
\text { prestasi sepakbola di } \\
\text { Pusdiklat Putra } \\
\text { Batang }\end{array}$ \\
\hline 5 & $\begin{array}{l}\text { Dukungan orangtua terhadap } \\
\text { pembinaan prestasi sepakbola di } \\
\text { Pusdiklat Putra Batang }\end{array}$ & $\sqrt{ }$ & - & 5 & $\begin{array}{l}\text { Dukungan orangtua } \\
\text { terhadap pembinaan } \\
\text { prestasi sepakbola di } \\
\text { Pusdiklat Putra } \\
\text { Batang }\end{array}$ \\
\hline 6 & $\begin{array}{l}\text { Dukungan masyarakat terhadap } \\
\text { pembinaan prestasi di Pusdiklat Putra } \\
\text { Batang }\end{array}$ & $\sqrt{ }$ & - & 6 & $\begin{array}{l}\text { Dukungan } \\
\text { masyarakat terhadap } \\
\text { pembinaan prestasi } \\
\text { di Pusdiklat Putra } \\
\text { Batang }\end{array}$ \\
\hline 7 & $\begin{array}{l}\text { Program latihan sepakbola yang telah } \\
\text { dilaksanakan di Pusdiklat Putra } \\
\text { Batang }\end{array}$ & - & $\sqrt{ }$ & 7 & $\begin{array}{l}\text { Program latihan } \\
\text { sepakbola yang telah } \\
\text { dilaksanakan di } \\
\text { Pusdiklat Putra } \\
\text { Batang }\end{array}$ \\
\hline
\end{tabular}

Keterangan:

B : Baik dengan kriteria tercapai $81 \%$ -

$100 \%$ dari aspek yang dinilai
C : Cukup baik dengan kriteria tercapai

60\%-80\% dari aspek yang dinilai

$\mathrm{K}$ : Kurang baik dengan kriteria tercapai 0-

$59 \%$ dari aspek yang dinilai 


\section{SIMPULAN}

Berdasarkan hasil penelitian dapat disimpulkan bahwa pembinaan prestasi Sepakbola di Pusdikklat Putra Batang termasuk cukup. Atlet yang berkualitas, pelatih yang kapabel memiliki peran dominan dalam pembinaan prestasi ditambah dengan dukungan moril materiil dari orangtua atlet, pengurus dan masyarakat, sedangkan untuk sarana dan prasarana masih kurang. Saran yang dapat diberikan yaitu; 1) diharapkan Pusdiklat Putra Batang melakukan kerjasama dengan pihak-pihak atau instansi lain yang bisa diajak memajukan dan mengembangkan keberadaan pembinaan latihan di Pusdiklat ini, 2) diharapkan Pusdiklat Putra Batang memiliki lapangan sendiri, 3) meningkatkan penggalian dana dan mengatur alirannya agar tepat sasaran, 4) menambah jumlah pelatih yang berkualitas, 5) merealisasikan program-program yang telah disusun dan direncanakan.

\section{DAFTAR PUSTAKA}

Fraliantina, I. (2016). Pengaruh Kepemimpinan Dan Sarana Prasarana Olahraga Terhadap Prestasi Sekolah Di Bidang Olahraga. JUARA : Jurnal Olahraga, 1(2), 100-109. Retrieved from

http://jurnal.upmk.ac.id/index.php/j uara/article/view/24

Undang-undang Republik Indonesia No.3 Tahun 2005 Kemenegpora RI

KONI (1997).Pedoman Pembentukan dan Pembinaan Klub Olahraga.KONI pusat. Jakarta.

Rusli Lutan. (1998). Perencanaan dan Strategi Pembelajaran Penjaskes. Jakarta: Depdikbud-Dikdasmen.

Bompa, Tudor. O (1994). Theory and Methodology of Training: The Key to athletic Performance. ThirdEdition. Dubuque: Kendal/ Hunt publishing Company.

Sugiyono. 2009. Metode Penelitian Pendidikan Pendekatan Kuantitatif, Kualitatif dan $R \quad \& \quad D$. Bandung: Alfabeta. 